\title{
MEMÓRIA E SILÊNCIO: A ESPOLIAÇÃO DAS LEMBRANÇAS*
}

Bruno Konder Comparato

Este artigo busca explorar as relações entre a experiência da tortura e as diferentes maneiras de lidar com os traumas dela decorrentes. Apesar da tortura constituir uma experiência única que é apreendida de maneira singular por cada indivíduo, alguns padrões podem ser verificados no que diz respeito ao modo de processar esses episódios e ressignificar nosso lugar no mundo, de acordo com a perspectiva de David Le Breton (2010). O recente debate em torno da Lei de Anistia e da criação de uma Comissão da Verdade no Brasil evidencia de maneira surpreendente que várias vítimas da ditadura concordam com os seus algozes no que diz respeito ao significado da Anistia. Ao invés de se considerarem vítimas, se veem como combatentes de uma guerra e consideram que qualquer retorno ao passado é desnecessário.

A partir de uma análise de dois movimentos sociais de grande envergadura do final da ditadura, o Movimento pela Anistia e a Campanha pelas Diretas Já, e das trajetórias que

\footnotetext{
* Uma versão preliminar deste artigo foi apresentada no GT Saúde, Emoção e Moral, no $36^{\circ}$ Encontro Anual da Anpocs (Associação Nacional de Pós-Graduação e Ciências Sociais), realizado em outubro de 2012.
} 
seguiram alguns dos seus protagonistas, pretendo mostrar que a maneira de processar o sofrimento representado pela tortura pode estar relacionada com a opinião a respeito da Comissão da Verdade. Ao rever os debates que acompanharam as lutas destes dois movimentos sociais importantes que marcaram o final do regime militar, o Movimento Brasileiro pela Anistia e a Campanha pelas Diretas Já, a questão de gênero se revelou uma abordagem interessante para compreender tanto o que estava em jogo à época como a trajetória dos seus principais protagonistas desde então.

\section{Memória e silêncio}

Assim como há várias verdades, o silêncio pode ter vários significados e nem todos silenciam pelas mesmas razões. Há aqueles que, simplesmente, não querem que a verdade venha à tona. Mas há outros que já resolveram suas questões com o passado e não querem remexer em episódios dolo146 rosos que a muito custo conseguiram processar. Somente assim é possível entender como personagens que estavam em campos opostos durante a ditadura hoje relutam em romper o silêncio. Não são poucos os exemplos em que a opinião das vítimas de tortura coincide com a de seus algozes, e o que uns consideram como desnecessária, outros chamam de revanchismo. O que parecem esquecer, contudo, é que a estratégia do silêncio deixa muitas perguntas sem resposta, e que estas acabam inevitavelmente por se tornarem necessárias.

Como entender o posicionamento público do hoje deputado federal Alfredo Sirkis (PV-RJ), por exemplo, que, tendo se iniciado na política em plena ditadura militar, ainda estudante secundarista, tendo integrado os quadros da Vanguarda Popular Revolucionária (VPR), participado diretamente da luta armada e vivido na clandestinidade, escreveu em artigo publicado recentemente: 
Não vejo utilidade numa Comissão da Verdade que me conforte em seu maniqueísmo. [...] Não há muita serventia cívica em ficar repisando o que já se sabe há tanto tempo: que houve torturas e execuções, com desaparecimentos autorizados pela cadeia de comando daquele regime. Não é mistério quem as praticou. [...] Com todo o respeito a quem sofreu o que eu não sofri - escapei da prisão e da tortura -, não vejo como politicamente positivo para o Brasil de hoje anular a "anistia recíproca" para julgá-los 40 anos mais tarde (Sirkis, 2012).

Muitos que quando jovens foram adversários do regime militar e dos seus excessos, alguns deles tendo inclusive pegado em armas para combater a ditadura, se consideram hoje satisfeitos com os rumos dos acontecimentos e com a posição a que chegaram após serem reintegrados à sociedade com a Lei de Anistia, como mostra o depoimento a seguir de Fernando Gabeira, que, enquanto militante do Movimento Revolucionário 8 de Outubro (MR-8), participou do sequestro do embaixador norte-americano Charles Elbrick em 1969:

É uma ilusão a gente pensar que a Comissão da Verdade, sozinha, vá alcançar um volume de dados muito grande. Ela vai desvendar muito de contribuições da sociedade e de contribuições investigativas da imprensa. Mas, de um modo geral, ela nunca descobre muita coisa. [...] Eu penso que a Lei de Anistia foi redigida num momento histórico em que uma correlação de forças existia, e eu comemorei e não me insurgi contra ela naquele momento. Eu achava que, considerada a correlação de forças que havia, era algo bom para nós. Agora mudou a correlação de forças. Mas não acho razoável, uma vez mudada essa correlação, dizer que agora a Lei de Anistia tem que mudar só porque somos mais fortes do que quando chegamos do exílio (Cecílio, 2012). 
É interessante confrontar estas posições com a afirmação da ex-presa política Maria Amélia de Almeida Teles, logo após a condenação do coronel Carlos Alberto Brilhante Ustra como torturador pelo Tribunal de Justiça de São Paulo, no dia 14 de agosto de 2012: "É preciso botar um fim na impunidade dos torturadores da ditadura militar." Num depoimento veiculado na televisão no ano anterior, no dia 5 de abril de 2011, Amelinha, como ela é conhecida pelos militantes dos direitos humanos, foi ainda mais contundente: "Não se consolida uma democracia com cadáveres insepultos, e nós temos muitos."

\section{0 apoio da sociedade civil}

Um marco importante nas iniciativas da sociedade para romper com o silêncio que abafava os crimes e excessos da ditadura, foi a instalação da Comissão Justiça e Paz pela Arquidiocese de São Paulo em agosto de 1972, sob o 148 comando do cardeal Dom Paulo Evaristo Arns. Para cumprir com o objetivo que consta em seus estatutos de "atuar como órgão de defesa da pessoa humana em todas as suas dimensões", a Comissão Justiça e Paz passou a reunir informações sobre prisões, buscando localizar os presos e tentar obstruir a tortura e oferecer proteção aos presos políticos dentro dos presídios, ao mesmo tempo que oferecia apoio aos familiares em sua sede na Cúria Metropolitana e recebia denúncias sobre desaparecimentos políticos (cf. Benevides, 2009, pp. 45-50).

Denunciar publicamente episódios de tortura não é uma tarefa simples, sobretudo quando as vítimas ainda temem o pior por parte dos agentes da repressão. Durante a ditadura militar no Brasil, um expediente muito utilizado consistia em buscar apoio junto a organizações de direitos humanos estrangeiras, que eram contatadas por jornalistas e correspondentes da imprensa internacional. Em seu livro de memórias, Dom Paulo relata o papel fundamental dos 
jornalistas estrangeiros para a divulgação das notícias sobre prisões, desaparecimentos e denúncias de tortura:

Lembro-me bem de uma ocasião em que o diretor do Deops me recebeu com esta frase: "Dom Paulo, como é possível? Ontem os líderes operários foram presos e hoje a BBC de Londres e os veículos mais influentes do mundo já publicam seus nomes e pormenores da prisão em dezenas e dezenas de nações!". Respondi-lhe, com muita simplicidade: "O senhor sabe que a Igreja é católica e o que significa este termo, não é? Significa 'difundido pelo mundo inteiro'. Gostaria tanto que o senhor nos desse boas notícias do Brasil e sobretudo de São Paulo para espalhá-las aos quatro cantos!" (Arns, 2001, p. 208).

Retrospectivamente, é espantoso constatar que não foram poucos os presos políticos que ousaram denunciar as torturas a que foram submetidos nos interrogatórios realizados para servir de instrução aos processos a que eram submetidos nos tribunais militares. De acordo com uma estimativa do ministro presbiteriano Jaime Wright, cerca de um terço dos processos chegava a ser submetido a um julgamento semipúblico em um dos doze tribunais militares de cinco juízes que agiam por todo o país, e, em $25 \%$ destes julgamentos, o prisioneiro ou os seus advogados denunciavam que a suposta confissão havia sido obtida sob tortura. Quando isso acontecia, as denúncias e os relatos de tortura eram transcritos nos autos pelos escrupulosos escrivães (cf. Weschler, 1990, p. 23). Não fosse a coragem desses presos políticos, não teria sido possível levar a cabo o projeto Brasil Nunca Mais, coordenado por Dom Paulo Evaristo Arns e Jaime Wright.

Entre 1979 e 1985, um pequeno grupo de trinta pessoas conseguiu reunir clandestinamente as informações a respeito de 1.800 episódios de tortura envolvendo 17 mil vítimas 
contidas em 707 processos relacionados aos julgamentos no Superior Tribunal Militar. Com o pretexto de consultar os arquivos para preparar as petições de anistia em nome de seus clientes ainda presos ou exilados, um grupo de advogados retirava as pastas dos processos por um período de 24 horas, tempo suficiente para fotografar tudo e enviar o material para ser guardado em um local seguro. O projeto todo foi mantido em segredo e as informações somente foram publicadas com o retorno à democracia (cf. Arns e Projeto Brasil Nunca Mais, 1985; Benevides, 2009; Weschler, 1990). Embora o regime militar jamais tenha admitido que usasse, em larga escala e sistematicamente, a tortura e o assassinato contra seus opositores, simplesmente negando a sua existência ou, quando as evidências não podiam ser contestadas, atribuindo os crimes a "excessos" de agentes que teriam agido à revelia do seu comando, numerosos episódios haviam sido devidamente registrados. Ao anun150 ciarem, em 1974, a intenção de devolver o poder aos civis por meio de uma "transição lenta, gradual e segura", que durou pouco mais de dez anos, os militares tiveram tempo para apagar todas as provas embaraçosas ou incriminatórias contra o regime. E mesmo assim,

[...] lá estavam as provas - nas próprias palavras deles, arrancadas dos seus próprios arquivos. Esses relatos de tortura eram, portanto, duplamente espantosos: em primeiro lugar, pela indiscutível autoridade - a inquestionabilidade - das declarações; e, em segundo lugar, pelo próprio fato, quase escandaloso, de que tais declarações ainda existissem (Weschler, 1990, p. 18).

Do lado da sociedade civil, o ato de fazer uma denúncia pública era menos arriscado, pois sempre era possível apresentar-se como um cidadão em busca de informações sobre o paradeiro de algum familiar. A dor era outra, menos física 
e mais emocional, mas não menos cruel, como mostra o relato feito por Dom Paulo Evaristo Arns no prefácio que escreveu para o livro Brasil: Nunca Mais:

Um dia, ao abrir a porta do gabinete, vieram ao meu encontro duas senhoras, uma jovem e outra de idade avançada. A primeira, ao assentar-se em minha frente, colocou de imediato um anel sobre a mesa, dizendo: "É a aliança de meu marido, desaparecido há dez dias. Encontrei-a, esta manhã, na soleira da porta. Sr. Padre, que significa essa devolução? É sinal de que está morto ou é um aviso de que eu continue a procurá-lo?”. Até hoje, nem ela nem eu tivemos resposta a essa interrogação dilacerante. A senhora mais idosa me fez a pergunta que já vinha repetindo há meses: "O senhor tem alguma notícia do paradeiro de meu filho?”. Logo após o sequestro, ela vinha todas as semanas. Depois reaparecia de mês em mês. Sua figura se parecia sempre mais com a de todas as mães de desaparecidos. Durante mais de cinco anos, acompanhei a busca de seu filho, através da Comissão Justiça e Paz e mesmo do Chefe da Casa Civil da Presidência da República. O corpo da mãe parecia diminuir, de visita em visita. Um dia também ela desapareceu. Mas seu olhar suplicante de mãe jamais se apagará de minha retina (Arns e Projeto Brasil Nunca Mais, 1985, pp. 11-12).

O que estes dois testemunhos evidenciam é o caráter individual do sofrimento causado pela violência política e o sofrimento a ela associado. O antropólogo David Le Breton (2010) assegura que toda dor remete a um questionamento sobre o nosso lugar no mundo. No caso da dor associada à violência, a questão moral do questionamento do lugar daquele que sofre no mundo surge de uma forma ainda mais aguda. Podemos considerar que a violência pode ser definida como uma relação desigual na qual uma parte sub- 
mete a outra, ao mesmo tempo que é relacionada com o indizível, pois representa uma experiência traumática. Fiona Ross, que estudou a Comissão de Verdade e Reconciliação da África do Sul, evidencia precisamente este ponto ao escrever sobre as

[...] complexidades do processo e sobre a decisão moral envolvida no ato de falar. [...] É preciso coragem tanto para falar sobre danos causados quanto para guardar silêncio diante deles e depois. Parte do que está em jogo no ato de falar sobre o estupro consiste em desmontar a familiaridade. Não são apenas relações específicas - entre a vítima e o estuprador - que são implicadas. Falar sobre o estupro é o mesmo que falar sobre sistemas de poder mais amplos que estão na base do mundo em que vivemos (Ross, 2010).

As mesmas considerações poderiam ser feitas a respeito 152 da tortura e da violência política.

É nesse sentido que se deve avaliar a relevância do Movimento pela Anistia e a sua importância na preparação do terreno para o retorno à democracia.

\section{0 movimento pela Anistia}

Criado em 1975 por Therezinha Zerbine, a esposa de um general cassado pelo regime militar pouco depois do golpe, o Movimento Feminino pela Anistia (MFPA) se transformou em pouco tempo num dos mais importantes movimentos sociais contra a ditadura no Brasil. Era o momento da emergência do movimento feminista no Brasil, que renasceu a partir da década de 1970, no quadro geral dos movimentos sociais da época, incentivado pela instituição do Ano Internacional da Mulher pela ONU em 1975, o que conferiu uma fachada de legalidade a uma luta que articulava as questões feministas com a oposição à ditadura militar, cujo resultado foi o reforço deste movimento 
como uma das forças mais significativas da luta pela anistia (cf. Sarti, 2004).

Outro aspecto importante é a consideração da anistia a partir do vocabulário dos direitos humanos e a afirmação de que ela não interessava apenas aos familiares das vítimas do regime, mas a todos os brasileiros. Ao fazer um balanço daquela luta, vinte anos depois, Helena Greco, que foi fundadora e presidente do MFPA/MG, avaliou que "Todas as palavras de ordem do movimento pela anistia ainda são válidas; é aí que se situa toda a sua importância. A partir da luta pela anistia, uma nova gramática dos direitos humanos foi estabelecida no Brasil” (apud Del Porto, 2009, p. 64).

Em 1978, o movimento se ampliou consideravelmente, com o surgimento dos Comitês Brasileiros pela Anistia (CBA), cujo objetivo era a defesa de um programa que incluía os seguintes pontos:

- anistia ampla, geral e irrestrita para aqueles considerados como criminosos políticos e "inimigos do regime";

- erradicação da tortura;

- elucidação das circunstâncias nas quais ocorreram torturas, mortes e desaparecimentos forçados;

- restituição dos restos mortais;

- responsabilização jurídica do Estado e dos agentes da repressão;

- desmantelamento do aparato repressivo;

- fim da Lei de Segurança Nacional e das "leis de exceção";

- fim do tratamento arbitrário e desumano contra os presos políticos; e

- reconquista do habeas corpus.

De acordo com a psicanalista Maria Auxiliadora Arantes, mais conhecida pelo apelido Dodora, que participou da fundação e foi uma das incansáveis diretoras do CBA/ 
SP e, junto com o jornalista Perseu Abramo e a socióloga Vanya Sant'Anna, constituiu o trio responsável pela redação de quase todos os documentos do CBA:

A luta pela Anistia Ampla, Geral e Irrestrita no Brasil se organizou no país ainda dominado pela ditadura militar. Por isso mesmo, todas as denúncias que então se fizeram e as formas de luta eram, em si, atos de coragem e de compromisso ético com a nação (Maués e Abramo, 2006, p. 231).

A partir de uma ampla organização da sociedade civil, foi criada o que constitui, talvez, a primeira experiência de um movimento em rede no Brasil, e isso num país ainda anestesiado pelo medo da reação dos militares. Nas palavras mais poéticas de Vanya Sant'Anna:

A imagem é banal, mas muito precisa: a luta pela Anistia foi um rio caudaloso, de águas abundantes trazidas por muitos outros rios que, no subsolo da terra brasileira, teimaram em continuar fluindo, apesar da aridez e da crueldade do regime militar que penalizou milhares de brasileiros (Maués e Abramo, 2006, p. 292).

Assim, a mesma Vanya Sant'Anna pode afirmar que

[...] a Campanha pela Anistia Ampla, Geral e Irrestrita, no final dos anos 1970, foi o primeiro movimento nacional e unificado contra a ditadura militar e representou a maior frente política de caráter progressista da história brasileira (Maués e Abramo, 2006, p. 291).

Naturalmente, os generais tinham outros projetos para o que acabou por se configurar como uma autoanistia. Para garantir a vitória do governo na sessão legislativa na qual 
foi votada a anistia parcial e recíproca desejada pelo alto comando militar, uma operação especial foi organizada no dia 22 de agosto de 1979, quando 800 soldados à paisana ocuparam as galerias do Congresso Nacional antes do dia amanhecer. Ao longo da tarde, contudo, militantes da campanha pela anistia conseguiram penetrar no local. A imprensa havia tornado pública uma mensagem da presidência que fazia um apelo imperativo pela aprovação sem emendas da proposta de lei enviada ao Congresso em substituição à proposta do CBA, caso contrário o presidente não hesitaria em exercer o seu direito de veto integral impedindo a aprovação da Lei de Anistia.

O projeto do CBA excluía claramente os violadores dos direitos humanos da anistia, ao afirmar que "são excetuados dos benefícios da anistia os atos de abuso ou tortura, quer tenham ou não resultado em morte, praticados contra prisioneiros políticos". A vitória do governo, contra o projeto de lei do CBA, foi garantida pela sua maioria numérica num congresso expurgado dos seus representantes mais críticos ao regime e pelas regras rígidas do processo legislativo. Mesmo com todas essas manobras, a vitória dos militares foi apertada, por apenas 206 votos contra 201 (cf. Zerbine, 1979; Teles, 2010; Greco, 2003).

Essa importância atribuída pelo CBA à definição clara dos que deveriam ser beneficiados pela anistia ilustra bem o que estava em jogo na época. Com efeito, apesar do costume de anistiar os inimigos do governo constituir uma tradição histórica no Brasil $^{1}$, em nenhum momento havia sido adotada anteriormente uma anistia recíproca, como a que os militares conseguiram aprovar.

Em consequência, a importância política da Lei de Anistia é bastante ambígua pois, se de um lado ela representa

\footnotetext{
${ }^{1}$ Num estudo sobre a questão, Roberto Ribeiro Martins (1978) identificou 84 episódios de anistia ao longo da história do país, que vão de 1664 a 1969.
} 
um avanço, ao ter permitido que cerca de 5 mil exilados pudessem retornar ao país, e tendo sido o resultado inegável de um importante movimento social de contestação da ditadura, de outro lado ela serviu para proteger os militares contra qualquer tipo de processo judicial de responsabilização dos seus atos com base em uma estranha ideia de anistia recíproca.

O texto da Lei de Anistia afirma que ela é outorgada “aos crimes políticos ou conexos a estes" $\left(\$ 1^{\circ}\right.$, art. $\left.1^{\circ}\right)$, isto é, todos os crimes em relação com aqueles cometidos por uma motivação política. O crime conexo seria, por exemplo, o roubo de um banco ou o furto de um carro, cometido por militantes políticos como uma forma de apoio à luta armada. Em nenhuma hipótese, contudo, a categoria de "crimes conexos" deveria ser invocada, como o fizeram os juízes, para justificar a anistia de crimes de tortura, desaparecimento forçado, ou até de assassinato, pois não 156 se trata de crimes conexos, mas de reações de um regime de exceção ao crime político de resistência. De acordo com esse raciocínio, o crime de resistência armada contra a ditadura, visando à desestabilização do regime, não poderia de maneira alguma ser associado aos crimes cometidos pelos torturadores em defesa da ditadura.

Faz-se necessário ressaltar que o entendimento de que a anistia diz respeito também aos crimes cometidos pelos militares ainda prevalece em amplos setores da sociedade. Recentemente, provocado por uma ação proposta pelo Conselho Federal da Ordem dos Advogados do Brasil a respeito da interpretação correta da Lei de Anistia, o Supremo Tribunal Federal decidiu, na sessão do dia 29 de abril de 2010, que a Lei garante a anistia tanto para as vítimas da ditadura como para os torturadores. $\mathrm{O}$ argumento central foi o de que a Lei de Anistia teria sido a expressão de um acordo político com vistas a uma conciliação nacional, e que uma eventual modificação somente poderia ser efeti- 
vada no Congresso. O ex-ministro dos Direitos Humanos, Paulo Sérgio Pinheiro, reagiu a essa decisão:

A Lei da Anistia não foi produto de acordo, pacto, negociação alguma, pois o projeto não correspondia àquele pelo qual a sociedade civil, o movimento da anistia, a $\mathrm{OAB}$ (Ordem dos Advogados do Brasil) e a heroica oposição parlamentar haviam lutado. Pouco antes de sua votação, em setembro de 1979 houve o Dia Nacional de Repúdio ao Projeto de Anistia do governo e, no dia 21, um grande ato público na praça da Sé promovido pela OAB-SP, igualmente contra o projeto do governo (Pinheiro, 2010).

Numa carta datada do dia 20 de julho de 1979 e endereçada ao Senador Teotônio Vilela, que havia presidido a Comissão Mista sobre Anistia do Congresso Nacional, os familiares dos presos políticos e desaparecidos advertiam: "Nós, como parte integrante da Nação brasileira, não aceitamos anistia pela metade, e muito menos aceitaremos mortes ou vidas pela metade" (Vilela, 1982, p. 534).

Este trecho é muito significativo, pois aqueles que corajosamente se insurgiram contra o regime e participaram da luta pela anistia fizeram uma opção sem ambiguidades e se entregaram por inteiro a um movimento popular que desafiava abertamente o núcleo duro da ditadura militar: a repressão.

Não faltam depoimentos emocionados daqueles que participaram da luta pela anistia, como este de Zilah Wendel Abramo:

As lembranças marcantes são inúmeras (a chegada de Flávia Schilling, a epopeia de Teotônio Vilela nas suas visitas aos presídios, a coragem da inesquecível Madre Cristina, quando, apesar da sua fragilidade, encontrou forças para enfrentar e expulsar um torturador que tinha se infiltrado numa reunião do Sedes; o grande comício em que reunimos 
10 mil pessoas na praça da Sé, a pomba que pousou na faixa da Anistia). Destaco especialmente duas, que revelam, além da coragem, a criatividade, a capacidade de improvisação que foram algumas das marcas da campanha:

- a chegada de Manuel da Conceição em Congonhas, vindo do exílio, quando ele foi carregado nos ombros dos circunstantes, numa verdadeira passeata improvisada no saguão do aeroporto, sob os olhos atônitos dos guardas armados, que não sabiam o que fazer diante de tanto atrevimento;

- a passeata organizada pelo CBA como repúdio à visita do ditador argentino Videla, e como homenagem às mães da praça de Maio. Só mulheres participaram: todas vestidas de preto, cada uma levando na cabeça um lenço branco com o nome de um dos mortos ou desaparecidos, vítimas do terror argentino. Não havia slogans nem palavras de ordem, somente cartazes e faixas com os nomes das vítimas. Desfilávamos em silêncio, e só se ouvia, de quando em quando, o barulho das matracas, ideia brilhante da atriz Ruth Escobar, que as havia encomendado na Penitenciária do Estado. Fomos do teatro Municipal ao largo São Francisco, onde os homens (maridos, pais, amigos, companheiros) nos esperavam apreensivos. Apreensão inútil: por onde passávamos, os populares abriam caminho, respeitosos, emocionados. Foram anos de muita emoção, de muita vibração, de muita solidariedade (Maués e Abramo, 2006, pp. 289-90).

Mesmo que a interpretação dada à Lei da Anistia possa ser hoje contestada, é legítimo considerar que o movimento pela Anistia constituiu o principal passo para a redemocratização e abriu o caminho para os grandes comícios que marcaram a campanha pelas eleições diretas. 


\section{Movimento pelas eleições diretas}

O segundo movimento social que destaco aqui é a campanha pelas eleições diretas que, de novembro de 1983 a abril de 1984, incendiou o país. Foram realizados cerca de 50 grandes comícios, iniciados pelo comício realizado no estádio do Pacaembu, em São Paulo, no dia 27 de novembro de 1983, e que reuniu 15 mil pessoas, e terminados de forma apoteótica com 1 milhão de manifestantes no comício da Candelária, no Rio de Janeiro, no dia 10 de abril de 1984, e 1 milhão e meio de pessoas no comício do Anhangabaú, em São Paulo, no dia 16 de abril de 1984. De acordo com a estimativa de Ulysses Guimarães, então presidente do principal partido de oposição, o PMDB, e um dos maiores entusiastas da Campanha pelas Diretas, tanto que ficou conhecido como o Sr. Diretas, $80 \%$ dos municípios do país teriam presenciado manifestações em favor das diretas, o que equivale a cerca de 4 mil comícios (cf. Leonelli e Oliveira, 2004, p. 362). Os depoimentos e as análises sobre aquele período frequentemente ressaltam o clima de otimismo, quase de euforia, que tomava conta dos participantes dos comícios, como se o país tivesse passado por uma catarse política.

Foram momentos de loucura, dias de vertigem durante os quais era muito difícil raciocinar com base nos padrões usuais da política brasileira. Naquele ano de 1984, a contagiante festa cívica fez com que acreditássemos todos que o golpe de misericórdia na ditadura militar estava ao alcance de nossas mãos (Rodrigues, 2003, p. 11).

"O povo desceu das arquibancadas e tomou conta de seu destino” (Juca Kfouri, “Nunca tinha visto isso antes”, apud Maués e Abramo, 2006, p. 407).

"Vi a história brotar nas ruas e na garganta do povo" (Ulysses Guimarães, em discurso na Câmara dos Deputados na tarde 
do dia 24 de abril de 1984, véspera da votação da emenda das eleições diretas, apud Leonelli e Oliveira, 2004, p. 541).

Podem os ministros da Justiça e do Exército, o presidente do PDS e seu líder na Câmara Federal continuar dizendo que o povo só engolfou a Candelária para ver artistas, deixa eles. Mal sabem que ali não dava para ver artista nenhum, que todo mundo estava mais preocupado em falar do que em ouvir, que o recado que queriam dar era só aquele, a sua presença, um grão de areia, na praia comum de um tempo novo. Amanhã, ninguém vai lembrar do nome deles, mas ninguém esquecerá, jamais, a beleza, a alegria, a ternura que se esparramou por esse Brasil afora, no embalo da Campanha das Diretas (Kotscho, 1984, pp. 17-18).

A organização da sociedade civil e a realização de grandes passeatas e manifestações nas ruas das grandes cidades ini160 ciada com o Movimento pela Anistia pode ter servido de inspiração para o movimento pelas Diretas. Muitos dos que estiveram na luta pela Anistia também foram às ruas para engrossar o coro pelas eleições diretas. Faz-se necessário, contudo, estabelecer diferenças claras entre os dois movimentos quanto aos seus objetivos e, sobretudo, quanto à postura dos principais protagonistas no que diz respeito ao encaminhamento das suas bandeiras.

Como foi exposto anteriormente, para os militantes da luta pela anistia, o apoio às lutas pelas liberdades democráticas era indissociável dos princípios dos direitos humanos. A diferença é clara quando se comparam estes objetivos aos dos principais personagens do movimento pelas diretas, que se resumiam, no fundo, à realização da eleição direta para presidente da república, de acordo com a emenda clara e objetiva de apenas quinze linhas proposta pelo deputado federal Dante de Oliveira (PMDB-MT) no dia 2 de março de 1983. 
Uma peculiaridade do regime autoritário instaurado no Brasil a partir do golpe de 1964 é que, diferentemente do que aconteceu durante o Estado Novo (1937-1945), o Congresso Nacional não foi fechado, os partidos não foram proibidos, e as eleições continuaram a ser realizadas regularmente, claro que de acordo com as regras impostas pelos novos donos do poder. Após ter expurgado o Congresso dos parlamentares de oposição mais aguerridos, os militares instituíram o bipartidarismo, que autorizava somente dois partidos: o governista partido da Arena, e a "oposição consentida” do MDB. Enquanto durou a ditadura, modificações regulares das regras eleitorais permitiram ao regime conservar a maioria legislativa, da qual dependia o controle do Poder Executivo. O Colégio Eleitoral, criado em 1967 para escolher o presidente da república era composto pelos membros do Congresso Nacional e por delegados de cada uma das assembleias estaduais (Soares, 1984, p. 100).

No contexto da época, insurgir-se contra o Colégio Eleitoral e clamar por eleições diretas para presidente da república soava como um desafio claro à autoridade do regime e às regras estabelecidas. Apesar disso, as palavras de ordem dos dois movimentos, Anistia ampla geral e irrestrita para o Movimento pela Anistia, e Diretas Já para o movimento pelas Diretas, representavam mensagens e conteúdos bem distintos. O mesmo pode se verificar com relação aos seus principais protagonistas.

De um lado, havia os cerca de 5 mil brasileiros exilados à espera da anistia e os familiares dos torturados e desaparecidos, considerados inimigos do regime, que estavam mais preocupados em reconstituir suas vidas destroçadas pela experiência do exílio e da repressão. As suas vozes ainda podem ser ouvidas nos dias de hoje, mesmo que em círculos restritos, apesar do silêncio que ainda impera e que é exemplificado pela censura imposta ao discurso que seria proferido por Vera Paiva, filha do deputado Rubens Paiva, assassi- 
nado pela ditadura, na cerimônia oficial do lançamento da Comissão da Verdade pela Presidenta Dilma Rousseff, com a presença dos cinco presidentes da república ainda vivos, eleitos a partir do retorno à democracia, em Brasília, no dia 18 de novembro de 2011.

De outro lado, temos vários políticos de destaque, que tiveram trajetórias políticas bem-sucedidas e cujas vozes foram muito ouvidas desde a redemocratização do país: Ulysses Guimarães, Franco Montoro, Tancredo Neves, Orestes Quércia, Pedro Simon, Leonel Brizola, Fernando Henrique Cardoso, Luiz Inácio Lula da Silva.

Questionada precisamente sobre este ponto, a socióloga Maria Victoria Benevides ${ }^{2}$, que pertenceu à Comissão Justiça e Paz e participou do Movimento pela Anistia e da Campanha das Diretas, considera que:

É claro que tem uma ligação, a grande diferença entre o pessoal da anistia e o pessoal das diretas, embora haja muita afinidade no sentido em que você encontra gente nos dois, é que o pessoal da Anistia era composto muito mais por familiares, mulheres, e pessoas que não tinham necessariamente nenhuma atuação política e nem ambição de entrar na vida política, não eram nem antigos políticos que tinham voltado, enquanto que nas diretas via-se toda a "classe política" entrando realmente para um jogo político. Claro que eles queriam as eleições diretas, e a prova é que quase saiu, foi uma diferença mínima de votos. Mas eles queriam o que desse, é aquela coisa típica do jogo político, pede-se o máximo mas o que for conseguido, já é um avanço.

No dia da votação da emenda Dante de Oliveira no Congresso Nacional, em 25 de abril de 1984, faltaram 22 votos para restabelecer a eleição direta para presidente.

${ }^{2}$ Em depoimento dado ao autor em 22 de agosto de 2012. 
As forças de oposição se reorganizaram rapidamente em torno da candidatura de Tancredo Neves (PMDB-MG), que acabou derrotando o candidato dos militares no Colégio Eleitoral. A bem da verdade, Tancredo Neves já vinha negociando nos bastidores. Avesso a um confronto aberto com o governo militar, mantinha restrições em relação ao movimento das diretas. Fez um acordo com Ulysses Guimarães (PMDB-SP): caso as eleições diretas fossem aprovadas, os méritos seriam todos para Ulysses Guimarães, caso fossem derrotadas, o PMDB apoiaria Tancredo Neves no Colégio Eleitoral.

No interior do próprio movimento pelas diretas, surgiu uma divisão entre aqueles que queriam exclusivamente a eleição direta sem negociação, e os outros que aderiram mesmo ainda durante a campanha ao Tancredo, à opção indireta, como explica Maria Victoria Benevides:

Eu falei no último comício das diretas, no Anhangabaú, como representante da Comissão Justiça e Paz e Direitos Humanos, e foi o que eu falei. Eu disse, eu tinha pouquíssimo tempo para falar, o palanque estava muito esvaziado dos grandes nomes, que estavam todos em Brasília. Eu disse "nós estamos todos aqui, lutando pelas diretas, mas as lideranças políticas do começo da campanha estão em Brasília negociando com Tancredo e com Sarney”.

Reportagens publicadas em dezembro de 1983 confirmam este fato ao relatarem um acordo firmado entre Tancredo Neves e Ulysses Guimarães, no qual o PMDB com Ulysses à frente levantaria a bandeira das eleições diretas até abril, quando, em caso de derrota, Tancredo articularia as negociações para a eleição indireta (cf. Bertoncelo, 2007, p. 111).

Benevides estabelece uma linha contínua que começa na luta pela anistia sem pactuação com os militares e os 
torturadores, passa pela reivindicação de uma Constituinte livre e soberana, apoia a revogação da Lei de Segurança Nacional, e defende a eleição direta sem negociação. Diante desse grupo mais principista, ela destaca outro que contemporiza e aceita abrir mão de princípios em nome da "política do possível”, como explica:

É interessante, porque até no âmbito de uma pequena comissão como a Comissão Justiça e Paz, esse racha apareceu, no sentido de que essa é a anistia possível e nós temos que nos agarrar com isso, [...] e também com relação à Constituinte livre soberana, que achavam que nós tínhamos que aceitar o Colégio Eleitoral. E o grupo que veio da Anistia, da Constituinte livre e soberana, fincou o pé, queria as diretas sem negociação.

Assim, as injunções da política eleitoral devem ser 164 levadas em conta para entender a evolução das trajetórias dos protagonistas da Campanha pelas Diretas. Pode-se considerar que os militantes de direitos humanos e os familiares dos mortos e desaparecidos ficaram associados à luta pela anistia, enquanto aqueles que desenvolveram uma carreira política posterior, mesmo que tivessem sido vítimas do regime militar e que se beneficiaram com a Lei de Anistia quando puderam retornar do exílio, tiveram seus nomes associados preferencialmente à Campanha pelas Diretas. Talvez a única exceção tenha sido o senador Teotônio Vilela, que, apesar de ter morrido no dia do primeiro comício das Diretas, no Pacaembu, teve seu nome associado às Diretas por seu envolvimento com a causa ao longo de todo o ano de 1983.

Nascido em uma família de usineiros de Alagoas, o senador Teotônio Vilela iniciou a carreira política na UDN e terminou no PMDB, abraçando todas as causas ligadas à redemo- 
cratização. A origem do apelido de "menestrel das Alagoas", que foi imortalizado em uma música de Milton Nascimento, está no seu discurso de despedida da carreira parlamentar, proferido no Senado em 30 de novembro de 1982:

Estou saindo desta Casa esta semana, isto não é despedida, mesmo porque não é do meu hábito despedir de nada. A vida política continua comigo, continuarei lutando lá fora, só não terei o privilégio de usar esta ou aquela tribuna. Quanto ao mais, prosseguirei na minha vida de velho menestrel, cantando aqui, cantando ali, cantando acolá, as minhas pequeninas toadas políticas ${ }^{3}$.

Mas quem melhor descreve a trajetória deste político extraordinário é o cartunista Henfil:

Dr. Aureliano Chaves, o senhor certamente conheceu o Teotônio Vilela. Ele, como o senhor era proprietário de terras, um usineiro. Assim como o senhor, ele veio da UDN. Assim como o senhor, ele fez o golpe de 64. Foram ambos para a Arena. E mais uma vez como o senhor, ele soube criticar o arbítrio que começava. Teotônio Brandão Vilela seguiu os arrancos da sua bravura e, como coragem não lhe faltava, decidiu-se transcender. Não ficaria conhecido como usineiro ou golpista. Escolheu o impossível: cortar suas próprias raízes autoritárias e virar um estadista. Como Bolívar, como Zapata, Teotônio Vilela hoje faz chorar de saudades qualquer praça pública do nosso país." (apud Rodrigues, 2003, p. 36).

No final da vida, Teotônio Vilela não era de contemporizar: "Democracia relativa é como farinha: enche a boca, mas não mata a fome" (Nery, 2002, p. 516). Tendo abraçado

${ }^{3}$ Publicado no Diário do Congresso Nacional, Brasília, DF, 2 dez. 1982. 
a causa da anistia, foi presidente da Comissão da Anistia no Senado, engrossou o coro por uma Constituinte livre e soberana, presidiu o Tribunal Tiradentes, organizado em 1983 pela Comissão Justiça e Paz para simular um julgamento da Lei de Segurança Nacional, e foi um entusiasta de primeira hora da Campanha pelas diretas. Doente e com os dias contados, Teotônio Vilela não tinha mais nada a perder e permitia-se até a pequenas provocações com os seus colegas de luta: "Diga a dr. Ulysses que desisti de morrer e vou ser candidato a presidente da República" (Leonelli e Oliveira, 2004, p. 187).

Outra é a trajetória de Lula, apesar de bastante significativa, como relata Maria Victoria Benevides,

[...] nessa linha de movimentos e lutas, o Lula ficou com o lado principista, com o grupo mais avançado da anistia, com a condenação da Lei de Segurança Nacional, com as Diretas, e com a Constituinte livre e soberana junto com o que nós estamos chamando de principistas. A mudança foi quando o partido avançou eleitoralmente, antes de ele chegar à presidência. A institucionalização do partido, o alargamento das alianças resultou numa reconsideração daqueles princípios. Essa questão principista explica muita coisa, mas, ao mesmo tempo, esses políticos sabem que precisam dos principistas. Não teria havido a mobilização toda das Diretas se não fosse o pessoal que acreditava mesmo, e lá ninguém ia dizer: "Ah, vamos fazer as Diretas, mas, se não der, a gente já tem o nosso candidato.” Com relação à anistia foi a mesma coisa.

Trata-se, aqui, de um ponto importante, que é a relação entre os direitos humanos e a política, pois se os direitos humanos estão baseados em princípios éticos que são, por definição, não negociáveis, como conciliálos com as necessidades da política que, esta sim, pressupõe 
a negociação? Se os defensores dos direitos humanos lutam pelo impossível, os políticos buscam os acordos possíveis (cf. Lefort, 1981).

\section{Tentativa de interpretação a partir da questão de gênero}

No caso específico do atual debate público sobre os cadáveres insepultos da ditadura, iniciado pela discussão a respeito da criação da Comissão da Verdade pelo governo federal, acredito ser interessante levar em conta a dimensão de gênero. Uma constatação simples é a de que, na linha de frente da defesa de uma comissão da verdade e da apuração dos crimes do passado, há mulheres que representam os mais variados segmentos da sociedade civil, enquanto do outro lado estão políticos, na maioria homens, que consideram que há assuntos mais urgentes e relevantes do que ficar remoendo o passado.

Como alerta Elizabeth Jelin (2003, p. 77), a menos que haja um esforço consciente e direcionado para considerar a questão a partir de uma perspectiva que leve em conta as questões de gênero, não há muitas chances de escapar de uma visão simplista e estereotipada, na qual as mulheres são vítimas e os militares homens dominam. A luta contra a repressão das ditaduras latino-americanas e os subsequentes movimentos sociais que lutam pela elucidação dos crimes, pela revelação dos abusos e pelo julgamento dos responsáveis nos oferecem uma série de imagens que podem ser interpretadas pela perspectiva de gênero. É o caso, por exemplo, das mães e avós da Praça de Maio, na Argentina, ou do Movimento de Mulheres pela Anistia, no Brasil. Do lado da repressão, a figura do torturador, assim como a dos militares, é claramente masculina. Não há exemplo de uma junta militar integrada por mulheres (Tabak, 1983, p. 67). Elizabeth Jelin observa que, na cobertura televisiva do caso Pinochet, no período que vai de sua prisão em Londres, em outubro de 1998, até sua liberação no Chile, em 
2001, a presença diferenciada de homens e mulheres era significativa. As mulheres encabeçavam as organizações de direitos humanos que clamavam por justiça e eram maioria nas manifestações de rua em apoio à prisão do ditador, assim como eram também mulheres que ofereciam os discursos mais inflamados em nome da preservação do legado histórico de Pinochet. Os homens, por sua vez, dominavam claramente nas instâncias institucionais relacionadas com o episódio, seja no papel de acusadores, defensores ou juízes (cf. Jelin, 2003, pp. 76-77).

Após observar que o conceito tradicional de participação política tende a considerar as formas institucionalizadas de manifestação, como a militância em partidos políticos, a integração a organizações profissionais, o exercício de mandatos eletivos, o voto e a eleição, Eva Alterman Blay (1988, p. 185) pondera que, quando se trata de aferir a participação das mulheres na política, tais critérios revelam baixa 168 participação e ocultam outro tipo de atuação, aquela realizada através de "formas novas e ousadas" pela mulher.

Este ponto de vista é corroborado pelo depoimento de Zilah Wendel Abramo, que participou da Comissão de Mães em Defesa dos Direitos Humanos, um grupo de mulheres organizado em junho de 1977 para apoiar os estudantes que protestavam contra o regime, e representava a Comissão de Mães na seção paulista do Comitê Brasileiro pela Anistia:

Num dado momento nós tomamos consciência de que não poderíamos continuar, cada uma de nós isolada em casa, angustiada e impotente, esperando cada fim de ato público, cada fim de passeata, sempre temendo o pior. Resolvemos criar um grupo que rompesse o que chamamos, na nossa carta de apresentação, a "cumplicidade passiva do silêncio", para assumir o apoio à luta dos estudantes, declarando publicamente a nossa concordância e a nossa identificação com os seus propósitos. Com isso pretendíamos 
desmoralizar a tese das autoridades, que tentavam passar a versão de que a revolta dos estudantes contra o regime era um aspecto particular da "luta de gerações". Fruto dessa tese era a pretensão de poder contar com a cumplicidade dos pais e mães para dissuadir os estudantes da sua luta. "Contenham os seus radicais, que nós conteremos os nossos", era o que "eles" diziam, exigindo uma promessa de bom comportamento futuro, quando estudantes detidos eram libertados. E nós, familiares, seríamos os fiadores desse bom comportamento. Era preciso responder com uma negativa veemente a essa pretensão, dizendo bem claramente que nosso objetivo não era conter o movimento estudantil, mas, ao contrário, apoiá-lo no que fosse possível (apud Maués e Abramo, 2006, pp. 288-289).

Elizabeth Jelin distingue duas reações "tipicamente femininas" que emergem em contextos ditatoriais: na esfera pública, elas criam e participam de organizações de direitos humanos que exploram o parentesco com as vítimas, enquanto na esfera privada se engajam na luta cotidiana pela subsistência familiar e os ajustes e mudanças precipitados pela prisão ou desaparecimento dos seus companheiros. Situações estas que são diferentes de uma separação ou divórcio, pois

[...] o clima de terror em que vivem muitas vezes requer

o silenciamento sobre o que aconteceu, a ponto de exigir a dissimulação do sofrimento pessoal. Para evitar despertar suspeitas, muitas mulheres fingem levar uma vida normal para os filhos, como se nada tivesse acontecido. O medo e o silêncio se fazem presentes a todo momento, a um custo emocional muito alto. Em muitos casos, a solidão é uma característica central da sua existência (Jelin, 2003, pp. 80-81). 
Faz-se necessário acrescentar também o tratamento diferenciado entre homens e mulheres quando se fala da memória pública das sociedades. De acordo com Michelle Perrot (1989, p. 9), que já dedicou vários estudos sobre o assunto, as mulheres constituem uma categoria indistinta, destinada ao silêncio: "No teatro da memória, as mulheres são sombras tênues. A narrativa histórica tradicional reserva-lhes pouco espaço, justamente na medida em que privilegia a cena pública - a política, a guerra - onde elas pouco aparecem."

Mesmo que as mulheres assumam hoje em dia várias posições públicas antes reservadas aos homens, elas ainda conservam uma atuação privilegiada quando se trata de manter a memória e a união familiar, como explica Michelle Perrot (1989, p. 15):

Assim, os modos de registro das mulheres estão ligados 170 à sua condição, ao seu lugar na família e na sociedade. O mesmo ocorre com seu modo de rememoração, da montagem propriamente dita do teatro da memória. Pela força das circunstâncias pelo menos para as mulheres de hoje (o que não é pouco), é uma memória do privado, voltada para a família e o íntimo, à qual elas foram de alguma forma delegadas por convenção e posição. Às mulheres cabe conservar os rastros das infâncias por elas governadas. Às mulheres cabe a transmissão das histórias de família, feita frequentemente de mãe para filha, ao folhear álbuns de fotografias, aos quais, juntas, acrescentam um nome, uma data, destinados a fixar identidades já em via de se apagarem. Às mulheres, o culto aos mortos e o cuidado dos túmulos, pois é de sua incumbência o cuidado das sepulturas.

A história das lutas feministas evidencia uma articulação constante entre as esferas pública e privada, como pode ser 
aferido a partir das bandeiras coletivas que emergem da luta política das mulheres. Algumas delas podem perfeitamente ser ressignificadas para o contexto do debate atual sobre a comissão de verdade: "o pessoal é político", "o silêncio é cúmplice da violência”, "nossos corpos nos pertencem”, "filho não é só da mãe". Os movimentos feministas elaboraram críticas contundentes à separação e oposição entre o público e o privado, bem como aos papéis e estereótipos sexuais associados a essas esferas: o público como espaço dos homens, e o privado como espaço das mulheres. Nesse sentido, "ao construírem o pessoal e o privado como espaço político, deram uma imensa contribuição ao pensamento social e político" (Rodrigues, 2005, p. 16). Cristina Wolff constata que as mulheres que se engajavam na luta armada eram vistas como ocupando um lugar de poder masculino. Ela relata um depoimento de Maria Amélia Almeida Telles, que foi militante do PC do B e esteve na guerrilha do Araguaia, de acordo com o qual "não se podia falar em feminismo, isso era coisa de pequeno burguês”. Mais tarde, contudo, muitas das jovens guerrilheiras e militantes, a partir do exílio ou de suas trajetórias posteriores, tornaram-se feministas (cf. Wolff, 2007, p. 22).

Faz-se necessário, portanto, levar em conta que não é adequado falar de uma maneira geral sobre "a mulher", sendo preferível falar sobre "as mulheres", o que abre o campo para toda uma diversidade de experiências e visões de mundo (cf. Jelin, 1996, p. 179). Ora, é justamente essa identidade com o mundo que é devastada pela experiência traumática limite que constitui a tortura (Le Breton, 2010, p. 147). Esse aspecto já foi evidenciado pelos psicanalistas:

[...] qualquer que seja a origem cultural dos pacientes, o vivido relacionado com a tortura e a desordem por ela provocada se manifestam de forma similar. Uma vítima de tortura turca ou chilena se parece mais com uma vítima de 
tortura marroquina do que com um compatriota turco ou chileno que não foi torturado e não teve que se confrontar com a violência política (Sironi, 1999, p. 48).

Nessas condições, romper o silêncio nem sempre é fácil. Como conciliar a necessidade de elaborar uma narrativa pública com o desejo de recuperar a intimidade e a privacidade violadas pela tortura? Testemunhar o sofrimento pode constituir uma tarefa difícil pois, em última instância, confirma a superioridade do torturador. Qualquer menção ao ocorrido evoca a dor, a ruptura identitária, a vergonha de ter sido submetido a tratamento tão doloroso (cf. Le Breton, 2010, p. 148). Faz-se necessário considerar a possibilidade bem real de que uma eventual convocação para testemunhar na Comissão da Verdade possa despertar fantasmas do passado, pois o que os torturadores buscavam também era a verdade. Mentir sob tortura constitui um

172 ato de coragem e civismo, como testemunha a resposta da então Chefe da Casa Civil Dilma Rousseff à provocação do senador José Agripino Maia (DEM/RN), quando convocada a depor na Comissão de Infraestrutura do Senado, no dia 7 de maio de 2008:

Eu tinha 19 anos, eu fiquei três anos na cadeia, e eu fui barbaramente torturada, senador. E qualquer pessoa que ousar dizer a verdade para os interrogadores compromete a vida dos seus iguais, e entrega pessoas para serem mortas. Eu me orgulho muito de ter mentido, senador, porque mentir na tortura não é fácil. Agora, na democracia se fala a verdade. Diante da tortura, quem tem coragem e dignidade fala mentira.

Há que se levar em conta também o sentimento de culpa por ter sobrevivido enquanto outros companheiros de luta morreram. "Sair inteiro da tortura acarreta um senti- 
mento de dívida difícil de ser resgatada, a interrogação persistente de saber porque sobrevivemos onde tantos desapareceram" (Le Breton, 2010, p. 148).

Os silêncios das narrativas das vítimas dos regimes de exceção são eloquentes. Não se trata de meros "lapsos" de memória, mas de "decisões pessoais de omitir detalhes como uma maneira de levar a cabo e controlar a reconstrução da identidade" (Pollak e Heinich, 1986, p. 5). Trata-se de encontrar o meio mais adequado para fazer a "gestão do indizível" que, naturalmente, varia consideravelmente em função das experiências e das histórias pessoais de cada indivíduo.

A fronteira entre o dizível e o indizível, o confessável e o inconfessável, separa uma memória coletiva subterrânea da sociedade civil dominada ou de grupos específicos, de uma memória coletiva organizada que resume a imagem que uma sociedade majoritária ou o Estado desejam passar e impor (Pollak, 1989, p. 8).

Nessa perspectiva é que a memória adquire uma importância política e que a contestação da "memória oficial" pode representar um sério desafio aos poderes constituídos e servir de teste para a capacidade da sociedade de lidar com o dissenso. No caso da sociedade brasileira, em que sempre se privilegiou o acordo e a conciliação, os assuntos espinhosos são relegados à esfera privada, sobretudo quando relacionados com o passado. Isso talvez explique porque o debate em torno da comissão da verdade é tratado como se fosse um assunto particular entre os familiares dos mortos e desaparecidos, de um lado, e a parcela dos militares que se sente solidária aos torturadores, de outro lado, com o governo atuando como um juiz, que mantém uma postura de neutralidade, e o resto da sociedade a assistir, meio sem compreender o que está em jogo. 


\section{Bruno Konder Comparato}

é doutor em Ciência Política pela USP e professor do Departamento de Ciências Sociais da Unifesp.

\section{Bibliografia}

ARNS, D. P. E. 2001. Da esperança à utopia - testemunhos de uma vida. Rio de Janeiro: Sextante.

ARNS, D. P. E.; PROJETO BRASIL NUNCA MAIS. 1985. Brasil: Nunca Mais

- um relato para a história. São Paulo: Vozes.

BENEVIDES, M. V. M. 2009. Fé na luta: a Comissão Justiça e Paz de São

Paulo, da ditadura à democratização. São Paulo: Lettera.doc.

BERTONCELO, E. 2007. A campanha das Diretas e a democratização. São Paulo: Humanitas.

BLAY, E. A. 1988. "A participação das mulheres na redemocratização". In: FLEISCHER, D. (org.). Da distensão à abertura: as eleições de 1982. Brasília: Ed. UnB.

CECÍlLIO, F. 2012. "Comissão da verdade não vai descobrir muita coisa, diz Gabeira”. R7 Notícias, Seção Brasil, 1 jul. 2012. Disponível em: $<$ http://noticias.r7.com/brasil/noticias/comissao-da-verdade-nao-

174 vai-descobrir-muita-coisa-diz-gabeira-20120701.html $>$. Acesso em: 11 jul. 2014.

DEL PORTO, F. B. 2009. "A luta pela anistia no regime militar brasileiro: a constituição da sociedade civil e a construção da cidadania”. Perseu: história, memória e política, ano 3, n. 3, pp. 43-72.

GRECO, H. A. 2003. Dimensões fundamentais da luta pela anistia. Tese de doutorado em História. Belo Horizonte: Universidade Federal de Minas Gerais.

JELIN, E. 1996. "Women, gender, and human rights". In: JELIN, E.; HERSHBERG, E. Constructing democracy - human rights, citizenship, and society in Latin America. Boulder: Westview Press.

2003. State, repression and the labors of memory. Minneapolis:

University of Minnesota Press.

KOTSCHO, R. 1984. Explode um novo Brasil: Diário da Campanha das Diretas. São Paulo: Brasiliense.

LE BRETON, D. 2010. Expériences de la douleur: entre destruction et renaissance. Paris: Éditions Métailié.

LEFORT, C. 1981. L'Invention démocratique. Paris: Fayard.

LEONELLI, D.; OLIVEIRA, D. 2004. Diretas Já: 15 meses que abalaram a ditadura. Rio de Janeiro: Record. 
MAUÉS, F; ABRAMO, Z. W. 2006. Pela democracia, contra o arbítrio: a oposição democrática, do golpe de 1964 à campanha das Diretas Já. São Paulo: Ed. Fundação Perseu Abramo.

MARTINS, R. R. 1978. Liberdade para os brasileiros: anistia ontem e hoje. Rio de Janeiro: Civilização Brasileira.

NERY, S. 2002. Folclore político. São Paulo: Geração Editorial.

PERROT, M. 1989. "Práticas da memória feminina”. A Mulher e o Espaço Público. Revista Brasileira de História, v. 9, n. 18, pp. 9-18.

PINHEIRO, P. S. 2010. "O STF de costas para a humanidade". Folha de S.Paulo, 5 maio 2010.

POLLAK, M. 1986. "La gestion de l'indicible". Actes de la Recherche en Sciences Sociales, v. 62-63, pp. 30-53.

1989. "Memória, esquecimento, silêncio". Estudos Históricos, v. 2, n. 3, pp. 3-15.

POLLAK, M.; HEINICH, N. 1986. "Le témoignage". Actes de la Recherche en Sciences Sociales, v. 62-63, pp. 3-29.

RODRIGUES, A. 2005. "Lugar de mulher é na política: um desafio para o século XXI”. In: SWAIN, T. N.; MUNIZ, D. C. G. Mulheres em ação: práticas discursivas, práticas políticas. Florianópolis: Ed. Mulheres.

RODRIGUES, A. T. 2003. Diretas Já: o grito preso na garganta. São Paulo: Ed. Fundação Perseu Abramo.

ROSS, F. 2010. "An acknowledged failure: women, voice, violence and the South African Truth and Reconciliation Commission”. In: ROALIND, S.; WALDORF, L. (orgs.). Localizing transitional justice. Stanford: Stanford University Press.

SARTI, C. A. 2004. "O feminismo brasileiro desde os anos 1970: revisitando uma trajetória”. Revista Estudos Feministas, v. 12, n. 2, pp. 35-50.

SIRKIS, A. 2012. "Complicando a verdade". O Estado de S. Paulo, 31 maio.

SIRONI, F. 1999. Psychologie de la torture. Paris: Odile Jacob.

SOARES, G. A. D. 1984. Colégio eleitoral, convenções partidárias e eleições diretas. Petrópolis: Vozes.

TABAK, F. 1983. "A resistência das mulheres aos regimes autoritários”. In: Autoritarismo e participação política da mulher. Rio de Janeiro: Graal.

TELES, J. A. 2010. "As disputas pela interpretação da lei de anistia de 1979”. IDÉIAS - Revista do Instituto de Filosofia e Ciências Humanas, v. 1, n. 1, pp. 71-93.

VILELA, T. 1982. Anistia. Vol. II. Brasília: Congresso Nacional - Comissão Mista sobre Anistia. 
MEMÓRIA E SILÊNCIO: A ESPOLIAÇÃO DAS LEMBRANÇAS

WESCHLER, L. 1990. Um milagre, um universo: o acerto de contas com os torturadores. São Paulo: Companhia das Letras.

WOLFF, C. S. 2007. "Feminismo e configurações de gênero na guerrilha: perspectivas comparativas no Cone Sul, 1968-1985”. História e Gênero. Revista Brasileira de História, v. 27, n. 54, pp. 19-38.

ZERBINE, T. G. 1979. Anistia: sementes da liberdade. São Paulo: Escolas Profissionais Salesianas. 


\section{MEMÓRIA E SILÊNCIO: A ESPOLIAÇÃO DAS LEMBRANÇAS}

\section{BRUNO KONDER COMPARATO}

Resumo: A partir da constatação surpreendente de que algumas vítimas da tortura durante a ditadura militar brasileira concordam com seus algozes no que diz respeito ao significado da Lei de Anistia, o artigo busca, na análise de dois movimentos sociais de envergadura no final do regime militar, respostas para o entendimento dessa realidade. $\mathrm{O}$ Movimento pela Anistia e a Campanha pelas Diretas Já, assim como as trajetórias que seguiram alguns dos seus protagonistas permitem afirmar que a maneira de processar o sofrimento representado pela tortura pode estar relacionada com a opinião a respeito da Comissão da Verdade. Ao rever os debates que acompanharam as lutas desses dois movimentos sociais, a questão de gênero se revelou uma abordagem interessante para compreender tanto o que estava em jogo à época como a trajetória dos seus principais protagonistas desde então.

Palavras-chave: Direitos Humanos; Tortura; Anistia; Diretas Já; Comissão da Verdade; Memória.

\section{MEMORY AND SILENCE: THE SPOLIATION OF MEMORIES}

Abstract: From the surprising finding that some victims of torture during the Brazilian military dictatorship agree with their torturers on the meaning of the Amnesty Law, the article analyses two important social movements appeared at the end of the military regime in search of answers to the understanding of this reality. The Movement for the Amnesty and the Campaign for the Direct Election of the presidency, as well as the trajectories that followed some of its protagonists, allow us to say that the manner in which is handled the suffering represented by torture can be related to the opinion about the truth commission. In reviewing the debates that accompanied the struggles of these two social movements, the gender issue has proved 
Resumos / Abstracts

an interesting approach to understand both what was at stake at the time, as well as the trajectory of its main protagonists since then. Keywords: Human Rights; Torture; Amnesty; Diretas Já; Truth Commission; Memory. 